\title{
OUTSOURCING TECHNICKEJ ŠTRUKTÚRY A SLUŽIEB ÚČTOVNÍCTVA POMOCOU VPN A TERMINÁLOVÝCH SLUŽIEB
}

\author{
Daniela Šusteková ${ }^{1}$
}

\section{Úvod}

Využívanie počítačových sietí a Internetu sa stalo neodmyslitel'nou súčast'ou rozvoja spoločnosti vo všetkých oblastiach. Internet ako celosvetová počítačová siet' rozšíril charakter ekonomiky ako celku. Využitie tejto siete poznačilo všetky komerčné, ale tiež nekomerčné subjekty, ktoré začali rozpoznávat' nové príležitosti poskytované Internetom.

Jedna zo služieb Internetu, ktorá má v poslednej dobe neslýchaný rozvoj, je elektronický obchod. Zahŕňa vel'a rôznych aktivít - od marketingových cez vystavovanie ponúk a objednávok. Výrazne vplýva na rozvoj podnikania a predstavuje aj aktivity podporujúce existenciu podniku.

Pod pojmom elektronický obchod nerozumieme len nakupovanie. Elektronický obchod má širší význam, zahŕňa vel’a rôznych aktivít - od marketingových cez vystavovanie ponúk a objednávok.

Jedna z oblastí, elektronického obchodovania je outsourcing. Možno povedat', že outsourcing podnikových procesov sa stal hlavným nástrojom zvyšovania výkonnosti podnikania a v mnohých spoločnostiach zároveň iniciátorom strategických zmien. Spoločnosti po celom svete využívajú výhody vyplývajúce z nakupovania podporných aktivít od špecializovaných spoločností, čo im umožňuje dosahovanie dlhodobých strategických ciel’ov pri súčasnom posilňovaní prevádzkovej efektivity Outsourcing prináša flexibilitu potrebnú v rýchlo sa meniacom podnikatel'skom prostredí, umožňuje organizácii získat' potrebnú konkurenčnú výhodu a realizovat' stanovené ciele.

\section{Popis technológie outsourcing}

Outsourcing $\mathrm{v}$ ekonómii označuje odovzdanie vnútropodnikových aktivít zvyčajne nesúvisiacich s hlavnou činnost'ou podniku na externý subjekt (ako napríklad subdodávatel’a). Outsourcing je špeciálna forma externého obstarávania predtým interne vykonávaných výkonov, pričom je zmluvne stanovená dížka a predmet výkonu, zakladá na odbere zdrojov z oblasti mimo podniku.

V oblasti informačných technológií sa využíva outsourcing technickej podpory vo forme hardvérového a softvérového vybavenia, inštalácie infraštruktúry a prevádzkovej podpory jej chodu. Outsourcing IT a Contracting sú najmodernejšie spôsoby poskytovania služieb v oblasti IT. Firma poskytujúca outsourcing preberá zodpovednost' v nasledujúcich oblastiach:

- Starostlivost' a zabezpečenie chodu IT

- Implementácia infraštruktúry IT

\footnotetext{
${ }^{1}$ RNDr. Daniela Šusteková, PhD. Žilinská univerzita, FPEDaS, KKMaHI, Univerzitná 1, Žilina, e-mail: sustek@fpedas.uniza.sk
} 
- Bezpečnost' infraštruktúry IT

- Správa serverov, siet'ových zariadení a pracovných staníc

- Podpora koncových užívatel'ov

- Servisné služby (aj pozáručné)

- E-business, hosting

- Outsourcing WWW sídla organizácie

\section{Využitie VPN na ochranu prenášaných údajov}

Vzhl'adom na skutočnost', že outsourcing je realizovaný využitím Internetu a Internet ako komunikačné médium je absolútne nedôveryhodné prostredie, je nutné toto pripojenie nejakým spôsobom zabezpečit'. Jedna z možností je využitie VPN - virtuálnych privátnych sietí.

Virtuálne privátne siete poskytujú riešenie, ako prepojit' počítače firmy na akékol'vek vzdialenosti, zabezpečit' ochranu prenášaných údajov a pritom využit' existujúce hardvérové a softvérové prostriedky Internetu. Takýmto spôsobom vznikne virtuálna siet' pre „výhradné“ použitie danej organizácie v prostredí sietí WAN. Podl'a typu komunikujúcich protistrán je možné virtuálne privátne siete rozdelit' na model označovaný ako side-to-side alebo gatewayto-gateway, kedy sa jedná o prepojenie dvoch vzdialených siet'ových brán. Takouto bránou je zariadenie, do ktorého z jednej strany prúdia siet'ové spojenia od všetkých lokálnych počítačov ukrytých vo vnútornej sieti a z druhej strany vychádzajú chránené údaje. Brána na druhej strane VPN prevedie chránené údaje do pôvodnej podoby a pokračujú ku počítačom, ku ktorým sú adresované. Takáto modelová situácia - nazývaná tiež tunelovanie. Je vel’a iných možností realizácie VPN, ale pre účely tohto článku ich nie je nutné uvádzat'.

V prípade outsourcingu sa VPN s tunelovaním využíva na pripojenie LAN siete zákazníka ku spoločnosti poskytujúcej outsourcing. Zákazník sa po pripojení do Internetu pripojí k smerovaču a vytvorí VPN tunel, cez ktorý sa dostane do siete tejto spoločnosti. Názorný príklad poskytuje popis konkrétnej realizácie, ktorá je uvedená v nasledujúcej časti článku.

\section{Popis konkrétnej realizácie - Outsourcing technickej štruktúry a služieb účtovníctva pomocou VPN a terminálových služieb}

Firma poskytujúca outsourcing, nazvaná pre zjednodušenie Konto, s.r.o., spracováva účtovníctvo podnikatel'om a spoločnostiam [obr.1]. Má zámer priblížit' sa so svojou službou zákazníkovi tak, aby nepocit’oval, že účtovníctvo je spracovávané externe. Má vybudovanú vlastnú počítačovú siet' s vyhradeným serverom s operačným systémom WINDOWS 2003 Server a SQL databázou. Počítačovú siet' rozšíri o d'alší server s WINDOWS 2003 Server a terminálovými službami (terminálový server) a zabezpečí pripojenie do Internetu cez rýchlu symetrickú linku. Pripojenie siete LAN do Internetu zabezpečuje router, ktorý vie vytvárat' VPN tunel so vzdialeným počítačom na Internete. Zákazník má rýchly DSL prístup na Internet.

Zákazník po pripojení do Internetu sa pripojí k smerovaču a vytvorí VPN tunel. Tunel vytvára smerovač a klientsky program na počítači zákazníka. Vzdialený počítač sa tak dostane do siete LAN Konto s.r.o. V sieti môže využívat' služby, ktoré mu správca siete povolil. Je to hlavne používanie programov informačného systému cez terminálové služby. Terminálový server je vo funkcií aplikačného servera. Programy, ktoré spúšt’a vzdialený zákazník, sú 
vykonávané na serveri a k zákazníkovi sa prenáša len obrazovka a tlač, na server sa prenášajú všetky vstupy myšou a klávesnicou. Zákazník aj externí účtovníci pracujú nad jednou databázou.

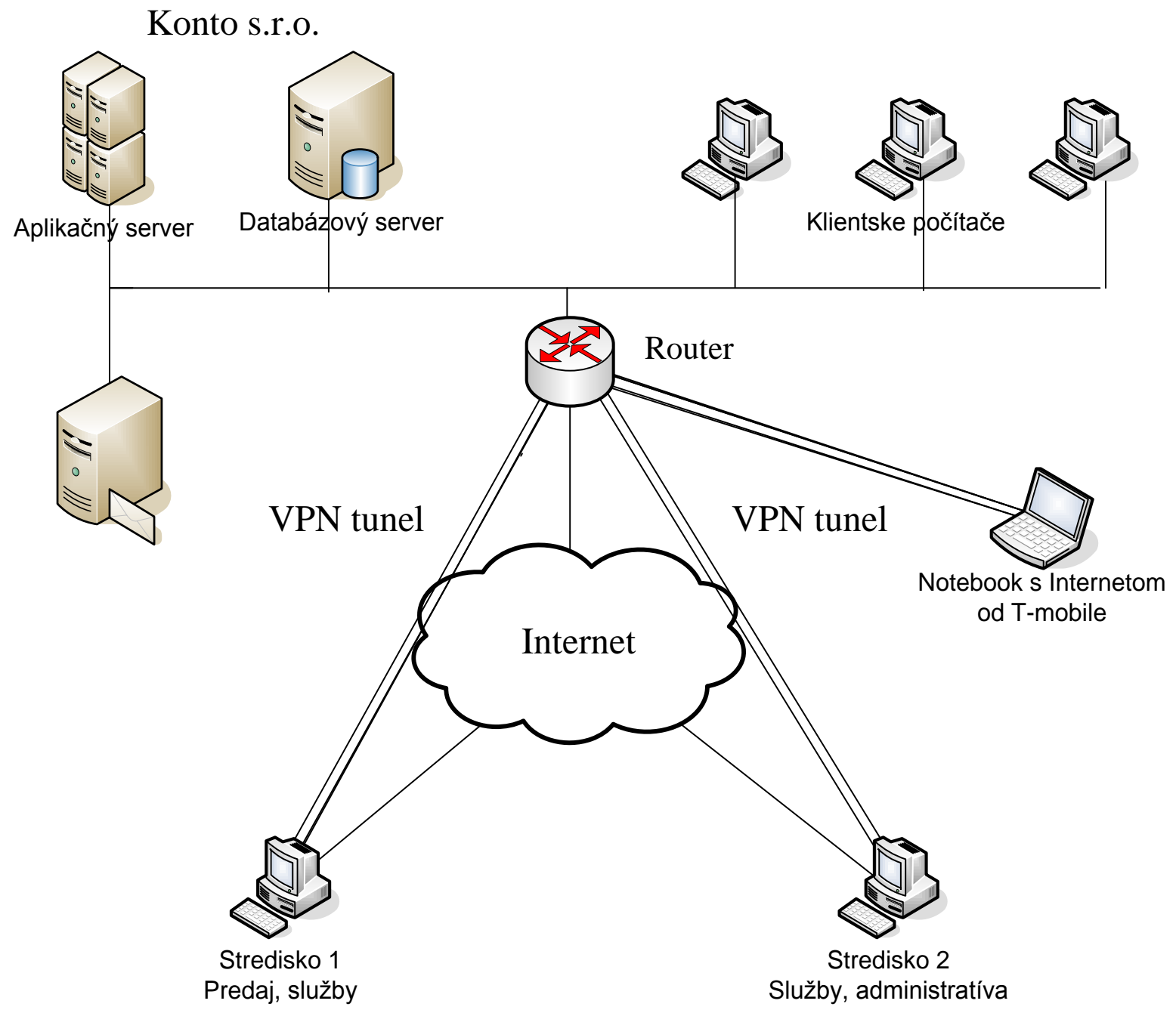

Obr. 1. Outsourcing technickej štruktúry a služieb účtovníctva pomocou VPN a terminálových služieb

\section{Popis činností vykonávaných prostredníctvom outsourcingu:}

Fakturácia

Zákazník vystavuje faktúry ako keby pracoval na svojej sieti. Ked’ vystaví faktúru, faktúra je automaticky zúčtovaná do účtovníctva.

Bankové operácie

Zákazník vidí stav svojich záväzkov a pohl’adávok a na základe aktuálneho stavu vytvára príkazy na úhradu. Program vytvorí elektronický príkaz na úhradu, ktorý odošle elektronickou poštou na homebanking svojej banky.

$\mathrm{Z}$ banky dostáva výpisy v v elektronickej forme a odosiela ich mailom do Konto s.r.o. na zúčtovanie.

\section{Finančná učtáreñ}

Zákazník skontroluje prijatú faktúru či je oprávnená. Zoskenuje ju, vypíše elektronickú „košiel'ku“ (informácie pre Konto s.r.o.) a mailom odošle faktúru do Konto s.r.o. Účtovník 
faktúru (súbor zo skenera) uloží do úložiska dát, faktúru zapíše do denníka prijatých faktúr a zaúčtuje ju.

Zákazník má prístup do programu len na čítanie. Vidí svoje záväzky, pohl'adávky, neplatičov a má k dispozícií všetky prehl'ady a analýzy, ako keby mal účtovníctvo na svojej lokálnej sieti.

Účtovníctvo

Zákazník má k dispozícií aktuálne výsledky účtovníctva, všetky výkazy sú aktuálne vd’aka tomu, že zákazník a Konto s.r.o. pracujú nad tou istou databázou.

Ak má zákazník viac stredísk, bez budovania technickej štruktúry má $\mathrm{k}$ dispozícií sumárne výsledky bez ohl'adu na to, kde sú strediská rozmiestnené, stačí mu, ak má prístup na Internet. Nepotrebuje kupovat' server a programy.

Konto s.r.o. je schopné poskytovat' služby viacerým zákazníkom. Po čase sú servery rozširované a Konto, s.r.o. má vytvorenú serverovú farmu. Technológia clustrovania serverov a diskové polia umožňuje bezpečnú, z hl’adiska zákazníka bezporuchovú prevádzku.

\section{Záver}

Outsourcing podnikových procesov sa stal hlavným nástrojom zvyšovania výkonnosti podnikania a v mnohých spoločnostiach zároveň iniciátorom strategických zmien. Spoločnosti po celom svete využívajú výhody vyplývajúce $\mathrm{z}$ predania podporných aktivít špecializovaným spoločnostiam.

\section{Literatúra}

[1] PUŽMANOVÁ, R.: Virtuální privátní síte = úspory a bezpečnost', Network Computing, 9/2003, ISSN 1214-3138, str. 23-27.

[2] MICROSOFT: Základy sítí Training Kit, Computer Press Brno 1999, ISBN 80-7226$158-4,806 \mathrm{~s}$.

[3] ŠUSTEKOVÁ D.: Počítačové siete a Internet, 1.vyd., vydavatel'stvo Žilinskej univerzity EDIS 2007, $155 \mathrm{~s}$.

[4] Professional Computing, Magazín pre IT profesionálov, DCD publishing s.r.o, ISSN 1214-5335 - 12 krát ročne

[5] PUŽMANOVÁ, R.: Moderní komunikační síte od A do Z, Computer Press Brno 2006, ISBN 80-251-1278 